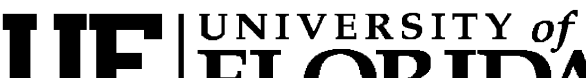 FLORIDA \\ IFAS Extension
}

\section{Root-Knot Nematode Resistance in Peanut ${ }^{1}$}

Jim Rich and Barry Tillman ${ }^{2}$

The domesticated peanut, Arachis hypogaea (L.) is widely used as an oilseed crop around the world and is a major agronomic crop in the southeastern United States. Peanut is produced on about 140,000 acres in Florida each year, and the state is the 4th largest producer in the USA. Production is concentrated in three areas of the state - the panhandle in and around Jackson County, the western panhandle in and around Santa Rosa County, and the central peninsular area in and around Levy and Gilchrist Counties. In Florida, about $90 \%$ of all peanut production is of the runner market types (small to medium-seeded). Several thousand acres of Valencia and Virginia market types are produced for the boiling trade.

\section{Root-Knot Disease of Peanut}

The peanut crop is subjected to numerous viral, fungal and nematode diseases, which are constant constraints to production faced by Florida farmers. Among the most serious include early and late leaf spot (Cercospora arachidicola and Cercosporidium personatum), southern stem rot (Sclerotium rolfsii), Cylindrocladium blackrot (Cylindrocladium parsiticum), tomato spotted wilt virus (Tospovirus, family Bunyaviridae) and root-knot (Meloidogyne arenaria race 1). The peanut root-knot nematode is the most serious nematode pest of the crop and arguably the most serious soil-borne disease problem. For example, the nematode is present in almost all fields where the crop is grown in the state and economic damage is estimated to occur in greater than $50 \%$ of these fields. Individual peanut fields heavily infested with the root-knot nematode have sustained yield losses greater than $75 \%$. In addition to causing considerable damage alone, it also increases the severity and incidence of other soil-borne diseases such as southern stem rot and Cylindrocladium blackrot.

\section{Symptoms of Root-Knot Disease}

Foliar symptoms of root-knot disease may be expressed at anytime during the growing season. These symptoms of nematode damage on peanut plants range from stunting, yellowing, wilting and even plant death (Figure 1). Generally, however, root-knot nematode damage symptoms are most evident in a peanut crop beginning about 100 days after planting and during or after periods of hot, dry weather. Areas of root-knot nematode damaged peanut are usually round to oblong in shape, and rows of infected plants may never overlap as those of

1. This document is ENY-057 (NG046), one of a series of the Entomology \& Nematology Department, Florida Cooperative Extension Service, Institute of Food and Agricultural Sciences, University of Florida. First published: November 2007. For more publications related to horticulture/agriculture, please visit the EDIS Website at http://edis.ifas.ufl.edu/.

2. Jim Rich, professor of nematology, and Barry Tillman, professor of agronomy, IFAS North Florida Research and Education Center, Institute of Food and Agricultural Sciences, University of Florida, Quincy, FL 32351.

The Institute of Food and Agricultural Sciences (IFAS) is an Equal Opportunity Institution authorized to provide research, educational information and other services only to individuals and institutions that function with non-discrimination with respect to race, creed, color, religion, age, disability, sex, sexual orientation, marital status, national origin, political opinions or affiliations. U.S. Department of Agriculture, Cooperative Extension Service, University of Florida, IFAS, Florida A. \& M. University Cooperative Extension Program, and Boards of County Commissioners Cooperating. Larry Arrington, Dean 
healthy plants. It is not uncommon for plants to wilt and eventually die in areas where nematode populations are high. Root symptoms are similar to that caused by all nematodes including a reduction in number of feeder roots and root stunting, but root-knot nematodes cause unique symptoms on roots and pods. Nematodes cause galls (knots) to form on both roots and pods of the peanut that are highly diagnostic for root-knot nematode presence compared to other nematodes affecting peanut. The presence of galls on roots, pegs and pods appears as single or multiple wart-like growths that may or may not be discolored (Figure 2). As root-knot nematode infection progresses, and generally later in the season, secondary root and pod rots cause further damage and eventual death of the plants.

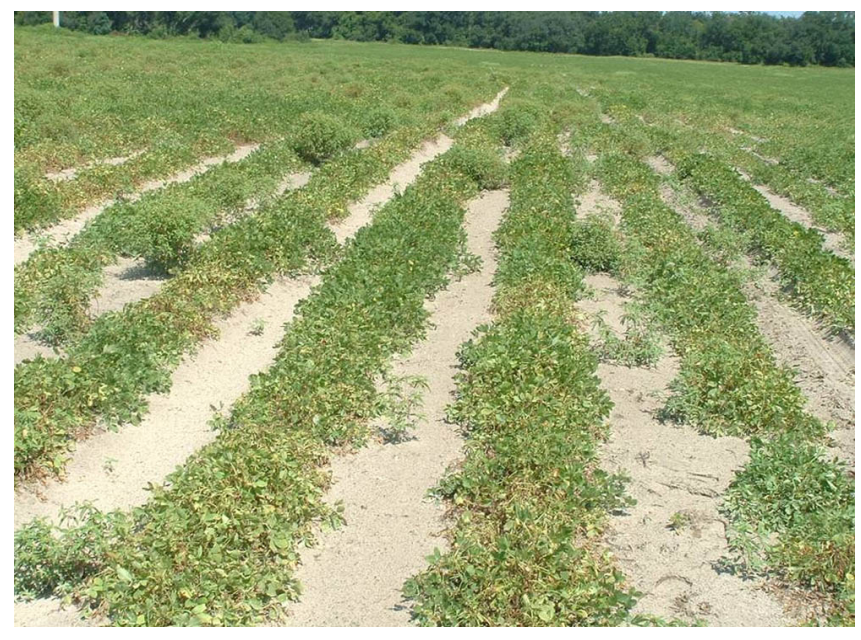

Figure 1. Peanut plants stunted by root-knot nematodes shown late in the growing season. The plants should fully cover the ground.

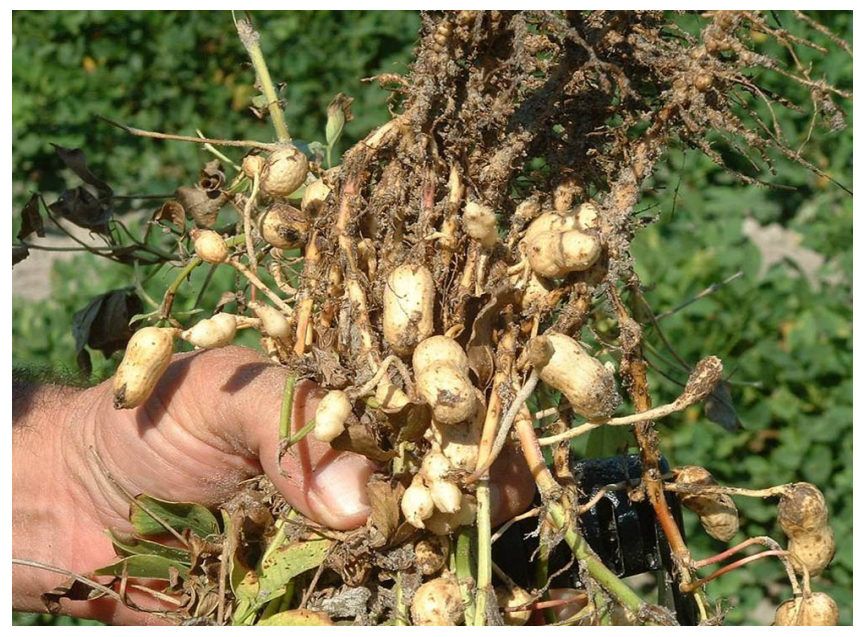

Figure 2. Damage to the lower roots and pods of peanut caused by peanut root-knot nematode.

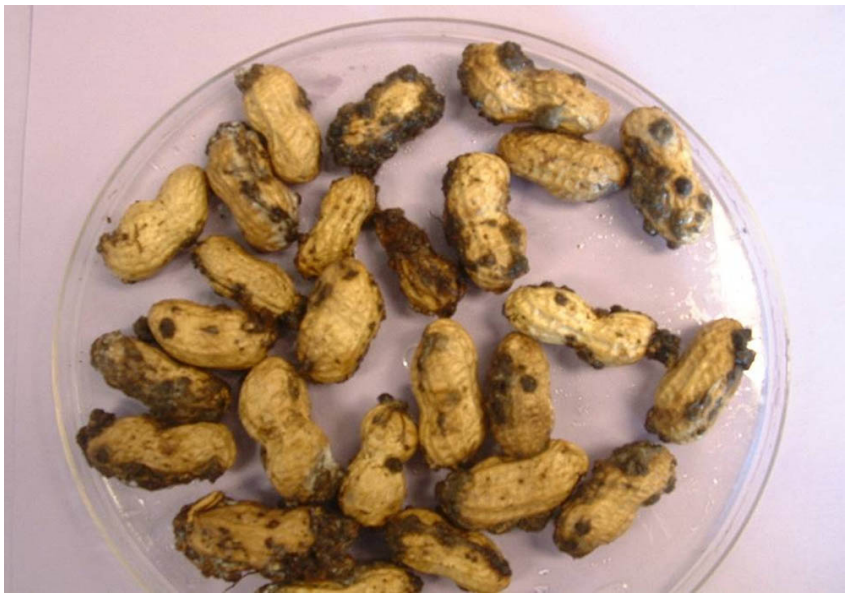

Figure 3. Severe galling on peanut pods. Many of the pegs and pods were destroyed; these are the surviving pods.

\section{Root-Knot Nematode Resistance in Peanut}

In the United States, considerable success has been achieved by plant breeders and plant pathologists in identifying and incorporating varying levels of resistance to plant diseases in commercial peanut varieties. Breeding cultivars with resistance to root-knot nematode, however, has been slower because no meaningful resistance has been found in the peanut germplasm collection of Arachis hypogaea. Also, the occurrence of the devastating tomato spotted wilt disease beginning in the 1990s diverted considerable attention away from breeding for resistance to other diseases including nematodes.

Only one root-knot nematode, $M$. arenaria race 1 , is a major nematode pest of peanut, and unlike most plants, peanut is a poor host or a non-host to other commonly found root-knot nematodes in Florida (M. incognita and M. javanica). Genes conferring resistance to peanut root knot nematode have not been found in cultivated peanut, but a number of other Arachis spp. have been identified that are highly resistant or immune to the peanut root-knot nematode. Simpson and Starr (1991) and Garcia et al. (1996) reported successful crosses to transfer a high level of nematode resistance into $A$. hypogaea. The resistance was obtained from a wild species, Arachis cardenasii. A germplasm line TxAG- 6 was generated by interspecific hybridization [A. batizocoi x (A. cardenasii x A. diogoi)]. Resistance was then introgressed into A. hypogaea by a backcross program with a component line of the 
variety Florunner (UF 439-16-10-3-2) as the recurrent parent. As a result, the first of the two root-knot nematode-resistant peanut cultivars (COAN) was released by the Texas Agricultural Experiment Station in 1999 (Simpson and Starr, 2001). The resistance in COAN is controlled by a single dominant gene and is expressed as a reduction in nematode reproduction. Although nematodes invade the roots of COAN, most emigrate from the roots, but the few that remain in the roots develop to reproductive adults (Bendezu and Starr, 2003).

The second peanut cultivar with resistance to the peanut root-knot nematode was released by the Texas Agriculture Experiment Station in 2002 and called NemaTAM. (Simpson et al., 2003). NemaTAM has greater yield potential than COAN and possesses the same level of resistance to the peanut root-knot nematode. It was derived from the same backcross introgression pathway as COAN but was selected from the seventh backcross generation whereas COAN was selected from the fifth backcross generation. Both COAN and NemaTAM have been proven resistant to the peanut root-knot nematode in a number of trials in the southeastern USA including in Florida. Unfortunately, neither peanut variety can be successful grown in Florida or the southeastern USA because they are highly susceptible to tomato spotted wilt virus and prevalent fungal diseases.

\section{Progress in Developing Nematode and TSW Resistance}

As indicated, several peanut cultivars are presently available that have resistance to either the peanut root-knot nematode or tomato spotted wilt virus, but until recently, no cultivars were available that have resistance to both pathogens. In 2007, the USDA released a cultivar, Tifguard, that has resistance to both tomato spotted wilt virus and root knot nematode. Its root-knot nematode resistance is derived from COAN but seed supplies will be limited for the next 2-3 years. In addition, the cultivar AP-3 from the University of Florida has been shown to have some tolerance to root knot nematodes. Seed supplies of AP-3 are readily available.

\section{Peanut Grower Options}

The standard recommendations for Florida peanut producers to minimize losses from root-knot nematode include rotation with crops that are poor or non-hosts of the nematode and use of nematicides as needed. However, recent research has shown that the peanut cultivar AP3 may provide some tolerance or resistance to the peanut root-knot nematode.

Over the years, a number of peanut varieties and lines produced from the UF/IFAS breeding program have been observed to show reduced nematode reproduction or damage from root-knot nematodes. The recently released AP3 has shown good yield in nematode-infested fields in Florida, and is recommended where other production factors or grower practices do not preclude its use. Another possibility for the central peninsular Florida producers may be to plant the resistant NemaTam peanut variety. This variety is not resistant to tomato spotted wilt virus and most other fungal diseases. However, the tomato spotted wilt virus is much less frequent and severe in that production area and growers may consider using NemaTAM, providing they fully utilize fungicide control programs in the production of this variety.

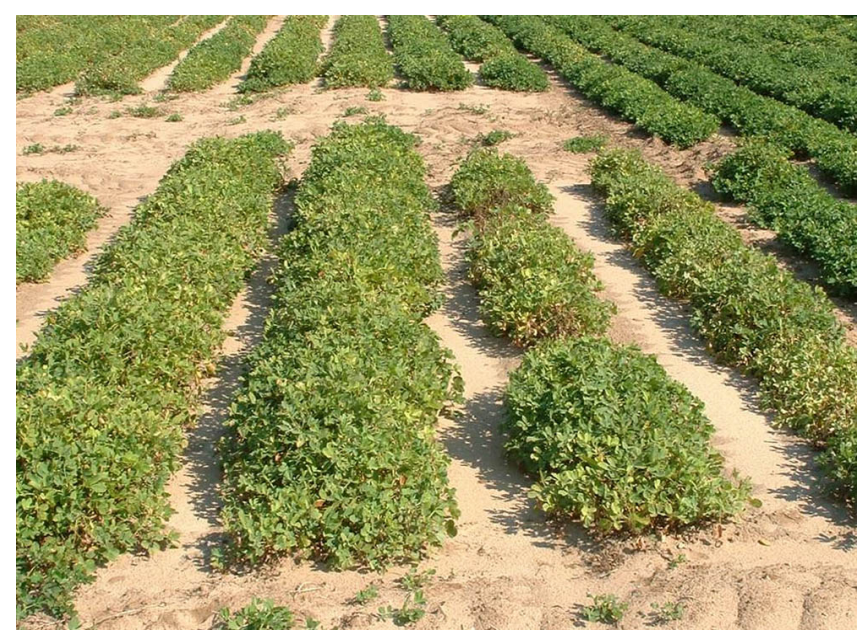

Figure 4. Left two rows showing a root-knot nematode tolerant peanut, right two rows are not tolerant to the nematodes.

\section{Promising Near Term Research}

Plant breeders and nematologists are actively pursuing the incorporation of root-knot nematode resistance into varieties adapted to the disease 
situation in the southeastern U.S. The new variety from the USDA program was named Tifguard and is expected to be released for grower use in 2009, while early crosses from the University of Florida program may be available as early as 2010 . These resistant varieties will not solve the peanut root-knot nematode problems in peanut production. However, they have the potential to reduce losses from this disease by $50 \%$ or more.

\section{References}

Bendezu, placeI. F., and J. L. Starr. 2003. Mechanism of resistance to Meloidogyne arenaria in the peanut cultivar COAN. Journal of Nematology 35:115-118.

Garcia, G. M., H. T. Stalker, E. Shroeder, and G. Kochert. (1996) Identification of RAPD, SCAR, and RFLP markers tightly linked to nematode resistance genes introgressed from Arachis cardenasii into Arachis hypogaea. Genome 39,836-845.

Simpson, C. E. 1991. Pathways for introgression of pest resistance into Arachis hypogaea L. Peanut Science 18:22-26.

Simpson, C. E., and J. L. Starr. 2001. Registration of COAN Peanut. Crop Science. 41:918.

Simpson, C. E., J. L. Starr, G. T. Church, M. D. Burrow, and A. H. Paterson. 2003. Registration of NemaTAM Peanut. Crop Science 43:1561. 